\title{
Article \\ Brain Atrophy and White Matter Damage Linked to Peripheral Bioenergetic Deficits in the Neurodegenerative Disease FXTAS
}

\author{
Jun Yi Wang ${ }^{1}$, Eleonora Napoli ${ }^{2}\left(\mathbb{D}\right.$, Kyoungmi Kim $^{3,4}$, Yingratana A. McLennan ${ }^{3,5}$, Randi J. Hagerman ${ }^{3,5, *,+}$ \\ and Cecilia Giulivi ${ }^{2,3, *,+} \mathbb{D}$
}

1 Center for Mind and Brain, University of California Davis, Davis, CA 95618, USA; jyiwang@ucdavis.edu

2 Department of Molecular Biosciences, School of Veterinary Medicine, University of California Davis, Davis, CA 95616, USA; enapoli@ucdavis.edu

3 The MIND Institute, University of California Davis Medical Center, Sacramento, CA 95817, USA; kmkim@ucdavis.edu (K.K.); yamclennan@ucdavis.edu (Y.A.M.)

4 Department of Public Health Sciences, School of Medicine, University of California Davis, Sacramento, CA 95817, USA

5 Department of Pediatrics, University of California Davis Medical Center, Sacramento, CA 95817, USA

* Correspondence: rjhagerman@ucdavis.edu (R.J.H.); cgiulivi@ucdavis.edu (C.G.)

+ Equal contributions.

Citation: Wang, J.Y.; Napoli, E.; Kim, K.; McLennan, Y.A.; Hagerman, R.J.; Giulivi, C. Brain Atrophy and White Matter Damage Linked to Peripheral Bioenergetic Deficits in the Neurodegenerative Disease FXTAS. Int. J. Mol. Sci. 2021, 22, 9171

https://doi.org/10.3390/ijms22179171

Academic Editor: George E. Barreto

Received: 3 July 2021

Accepted: 23 August 2021

Published: 25 August 2021

Publisher's Note: MDPI stays neutral with regard to jurisdictional claims in published maps and institutional affiliations.

Copyright: (c) 2021 by the authors. Licensee MDPI, Basel, Switzerland. This article is an open access article distributed under the terms and conditions of the Creative Commons Attribution (CC BY) license (https:// creativecommons.org/licenses/by/ $4.0 /)$.

\begin{abstract}
Fragile X-associated tremor/ataxia syndrome (FXTAS) is a neurodegenerative disorder affecting subjects (premutation carriers) with a 55-200 CGG-trinucleotide expansion in the 5'UTR of the fragile $\mathrm{X}$ mental retardation 1 gene (FMR1) typically after age 50 . As both the presence of white matter hyperintensities (WMHs) and atrophied gray matter on magnetic resonance imaging (MRI) are linked to age-dependent decline in cognition, here we tested whether MRI outcomes (WMH volume (WMHV) and brain volume) were correlated with mitochondrial bioenergetics from peripheral blood monocytic cells in 87 carriers with and without FXTAS. As a parameter assessing cumulative damage, WMHV was correlated to both FXTAS stages and age, and brain volume discriminated between carriers and non-carriers. Similarly, mitochondrial mass and ATP production showed an age-dependent decline across all participants, but in contrast to WMHV, only $\mathrm{FADH}_{2}-$ linked ATP production was significantly reduced in carriers vs. non-carriers. In carriers, WMHV negatively correlated with ATP production sustained by glucose-glutamine and $\mathrm{FADH}_{2}$-linked substrates, whereas brain volume was positively associated with the latter and mitochondrial mass. The observed correlations between peripheral mitochondrial bioenergetics and MRI findings-and the lack of correlations with FXTAS diagnosis/stages—may stem from early brain bioenergetic deficits even before overt FXTAS symptoms and/or imaging findings.
\end{abstract}

Keywords: aging; cognition; brain; MRI; volume; white matter hyperintensities; mitochondria; bioenergetics; peripheral blood monocytic cells; FMR1

\section{Introduction}

The onset of neurodegenerative diseases such as Alzheimer's disease (AD), Parkinson's disease (PD), Huntington's disease (HD), fragile X-associated tremor/ataxia syndrome (FXTAS), among others, is believed to be multifactorial; however, older age is the greatest risk factor [1-3]. Thus, it is likely that cellular and molecular changes associated with aging and/or premature senescence would promote neuronal abnormalities and degeneration. Among them, perturbation of cellular energy metabolism and mitochondrial biogenesis are commonly associated with aging. These changes in energy metabolism have been partly explained by decreased sensitivity to glucose signaling, uptake, and utilization [4] resulting in major metabolic disorders, which are also well-known contributors to neurodegeneration. 
Given that the brain is $2 \%$ of the body weight but accounts for $20 \%$ of the energy consumption in humans $[5,6]$, it is not surprising that a decline in mitochondrial bioenergetics often results in neuropsychiatric deficits [7]. The brain's high energy demand is met mainly by mitochondria-dependent glucose metabolism [8]. As such, neurons are the cells most vulnerable to reduced glucose supply due to their high energy demand. Energy failure is followed by an imbalance in the redox status and hyperexcitability, neuronal necrosis or apoptosis with dire consequences to brain trauma and neurodegeneration [9]. The mechanisms of age- and disease-dependent impaired energy production in the brain that significantly lower cognitive function and increase the risk for developing neurodegeneration are yet to be identified [10]. For instance, a significant reduction of glucose uptake in the brain is detected in prodromal [11-14] as well as symptomatic [15-17] stages of familial $\mathrm{AD}$, suggesting that abnormalities in neuronal energy metabolism and subsequent energy depletion are the earliest pathophysiological conditions prior to the onset of overt clinical manifestations of AD. The same phenomenon has also been observed in other neurodegenerative diseases such as HD and FXTAS [18-24]. Consistent with this premise, mitochondrial dysfunction, impairment of oxidative phosphorylation, and reduced glucose metabolism have been shown to be early pathological alterations in $\mathrm{AD}[25,26]$. Concomitantly to energy depletion, both reduced glucose uptake and mitochondrial dysfunction may cause a robust generation of reactive oxygen species (ROS), which would be an additional insult leading to accelerated damage in neurons [27-29], as oxidative damage is a known contributor to neurodegenerative processes [30-33].

Indeed, several dietary and pharmacological interventions have been designed to modulate cellular metabolism with anti-aging purposes as well as for slowing the progression of neurodegeneration. Among these, caloric restriction [34-37], administration of resveratrol [38] and metformin [39], and electroacupuncture [40] have recently emerged as promising therapeutic strategies with a common underlying mechanism, specifically the activation of SIRT1 and/or AMPK pathways and inhibition of mTOR signaling, leading to a slowing of the aging process and a decrease of the incidence of age-related neurodegeneration [41-43].

Our team was the first to report mitochondrial dysfunction as a common feature in biological samples including primary skin fibroblasts, peripheral blood monocytic cells (PBMCs), serum/plasma and postmortem brain tissues from carriers of the FMR1 premutation (defined as a moderate (55-200) CGG repeat expansion in the FMR1 gene) with and without FXTAS [23,24,44-46] as well as in murine models of the premutation [47]. However, to our knowledge, no study to date has characterized the putative correlation between biomarkers of neuronal or brain aging, associated with cognitive decline, and peripheral mitochondrial bioenergetic status. Only one other study reported a positive correlation between brain white matter hyperintensities (WMHs) scored from MRI and improved mitochondrial outcomes in Epstein-Barr virus (EBV)-transformed lymphoblasts in carriers of the premutation with and without FXTAS [48]. Such correlation may have resulted from the use of EBV-transformed lymphoblastoid cell lines (lymphoblast cell line or LCL). Despite the fact that cultured fibroblasts and LCL have been found to be extremely useful in the diagnosis of mitochondrial disorders [49,50], both systems have the disadvantage that the mitochondrial defect may or may not be expressed to the level that matches those of the primarily affected organ or tissue. Dissimilarities between these cell types rely on the fact that values for respiratory chain-deficient LCL are not nearly as elevated as they are for cultured skin fibroblasts. Because LCL are a transformed cell line, they do not go into the semiquiescent state of confluence, and have a constantly high ATP demand that tends to keep the redox states in a rather oxidized condition, confounding the detection of high lactate-to-pyruvate ratios for respiratory chain defects [49]. In addition, upon EBV transformation, LCL have been found to have higher mitochondrial biogenesis than lymphocytes [51], loss of methylation near the trinucleotide expansion of the myotonic dystrophy protein kinase gene [52], and higher formation of complex mtDNA arrangements [53], among other issues [54-59]. 
The presence and early detection of mitochondrial dysfunction, before the onset of overt clinical symptoms, would allow physicians to detect early signs of aging or premature aging in individuals at risk of developing neurodegeneration. This concept is based on the difference between the chronological age (based on the date of birth) and the biological one (internal clock). To address this gap in knowledge in the context of the neurodegenerative disease FXTAS, we sought to correlate brain volume (BV) and white matter lesions quantified using the WMH volumes (WMHV) — which were already reported as affected in carriers of the premutation [60] — with mitochondrial outcomes from terminally differentiated, non-proliferating peripheral blood mononuclear cells (PBMCs).

Our study indicates the feasibility of correlating MRI imaging with some peripheral bioenergetic markers, thereby providing the potential to identify those cases with early signs of premature aging and a potentially worse prognosis.

\section{Results}

\subsection{Demographic Characteristics of Participants Included in This Study}

This study enrolled 103 individuals (16 non-carriers, mean age (SD) 50 (18) years, range 24-73 years; 87 premutation carriers, mean age (SD) 63 (12) years, range 24-85 years) with available MRI studies and bioenergetic analyses of PBMCs except for 7 non-carriers who had only mitochondrial function assessment. About half of the participants were female (non-carriers: $4 / 16(25 \%)$, premutation carriers: $42 / 87(48 \%))$ ). Premutation carriers were grouped by FXTAS stage, which was scored by a trained physician (RJH) based on the severity of movement and gait impairments (stage 1: subtle or questionable signs, stages 2-6: clear tremor/balance problems with minor to severe interference of daily living; [61]). Premutation carriers at FXTAS stage $\leq 1$ were included under the PFX-group ( $\mathrm{N}=24,6$ males and 18 females, mean age (SD) 49 (13) years, range 24-71 years) whereas those at the FXTAS stages $\geq 2$ were grouped into PFX+ $(\mathrm{N}=63,39$ males and 24 females, mean age (SD) 69 (8) years, range 53-85 years).

\subsection{Smaller Brain Volume in Premutation Carriers Compared to Non-Carriers, and Higher WMHV in Carriers with FXTAS Stages $\geq 2$}

Multiple linear regression analysis was conducted to examine the effects of age, group (i.e., FXTAS status), sex, and age-by-group interaction on individual MRI outcomes. Brain scaling factor was included as a covariate for MRI outcomes to control individual differences in cranial size. The regression analyses revealed significant correlations between age and WMHV (directly) $(\beta=0.05 \pm 0.011 \log (\mathrm{mL})$, false discovery rate $(\mathrm{FDR})<0.001)$ and between age and BV (inversely) $(\beta=-3.18 \pm 0.62 \mathrm{~mL}, \mathrm{FDR}<0.001)$, while controlling for sex and group. There was also a sex difference in WMHV indicating that females had smaller WMHV than males (females $=3.32 \pm 3.83 \mathrm{~mL}$, males $=13.3 \pm 16.9 \mathrm{~mL}, \mathrm{FDR}=0.01$ ). However, in a post-hoc analysis including premutation carriers only in the regression analysis, the sex-differences in WMHV were not significant after adding FXTAS stage as a covariate $(p=0.06)$. Compared with non-carriers, PFX - exhibited smaller BV $(\beta=-52.2 \pm 24.4 \mathrm{~mL}$, $\mathrm{FDR}=0.05)$ with no difference in WMHV $(\beta=0.005 \pm 0.45 \log (\mathrm{mL}), \mathrm{FDR}=0.99)$ after adjusting for age and sex. In contrast, PFX+ exhibited significantly higher WMHV and smaller BV compared with both non-carriers $\left(\beta_{\mathrm{WMHV}} / \beta_{\mathrm{BV}}=1.54 \pm 0.52 \log (\mathrm{mL}) /-86.8 \pm 28.6 \mathrm{~mL}\right.$, both FDRs $=0.007)$ and PFX $-\left(\beta_{\mathrm{WMHV}} / \beta_{\mathrm{BV}}=1.53 \pm 0.36 \log (\mathrm{mL}) /-34.7 \pm 19.6 \mathrm{~mL}\right.$, FDR $<0.001 / 0.09$; Table 1, Figure 1A,B).

2.3. Lower Overall Oxygen-Linked ATP Production Fueled by Succinate in Premutation PBMCs but Higher with Glycerophosphate as Substrate in Carriers with FXTAS Stages $\geq 2$

Multiple linear regression analysis was conducted to examine the effects of age, group, sex, and age-by-group interaction on individual mitochondrial outcomes. Of the 11 mitochondrial outcomes tested in PBMCs, 6 (all log transformed) revealed significant age-dependent decreases across the 3 diagnostic groups ( $\beta=-0.035$ to -0.021 , FDR $<0.001-0.008$ ). Among these were two markers of mitochondrial mass (citrate synthase, and cytochrome $c$ oxidase or Complex IV activities), oxygen-linked ATP production 
by various segments of the electron transport chain sustained by NADH-, $\mathrm{FADH}_{2-}$, and alpha-glycerophosphate-linked substrates; and oxygen-linked ATP production fueled by glucose and glutamine (Table 1).

Oxygen-linked ATP production sustained by succinate ( $\mathrm{FADH}_{2}$-linked respiration), was lower in carriers, regardless of FXTAS diagnosis, compared to non-carriers after ageadjustment (PFX - vs. non-carriers $/ \mathrm{PFX}+$ vs. non-carriers: $\beta=-0.57 /-0.55, \mathrm{FDR}=0.10$ ) (Figure 1C, left panel). ATP production sustained by alpha-glycerophosphate was higher in $\mathrm{PFX}+$ as a group compared to PFX - after age-adjustment $(\beta=0.64$, FDR $=0.10$; Figure $1 \mathrm{C}$, right panel) suggesting either a decreased activity of the malate-aspartate shuttle or increased fatty acid oxidation to sustain the ATP demand. No sex differences were observed for peripheral mitochondrial outcomes in non-carriers. Unexpectedly, due to the X-linked nature of the disorder, no significant sex differences were observed for the carriers either.

Table 1. Effect of age and FXTAS stage diagnoses on MRI outcomes and peripheral mitochondrial bioenergetics.

\begin{tabular}{|c|c|c|c|c|c|c|c|c|c|c|c|c|c|}
\hline \multirow[b]{2}{*}{ Measures } & \multirow[b]{2}{*}{$N$} & \multicolumn{3}{|c|}{ Age } & \multicolumn{3}{|c|}{ PFX - vs. Controls } & \multicolumn{3}{|c|}{ PFX+ vs. Controls } & \multicolumn{3}{|c|}{ PFX+ vs. PFX- } \\
\hline & & $\begin{array}{c}\beta \\
\text { (SD) }\end{array}$ & $P$ & FDR & $\begin{array}{l}\beta * * \\
\text { (SD) }\end{array}$ & $P$ & FDR & $\begin{array}{l}\beta * * \\
\text { (SD) }\end{array}$ & $P$ & FDR & $\begin{array}{l}\beta * * \\
(\mathrm{SD})\end{array}$ & $P$ & FDR \\
\hline \multicolumn{14}{|c|}{$M R I$} \\
\hline $\begin{array}{c}\text { WMHV } \\
(\log )\end{array}$ & 96 & $\begin{array}{c}0.050 \\
(0.011)\end{array}$ & $<0.001$ & $<0.001$ & $\begin{array}{l}0.005 \\
(0.45)\end{array}$ & 0.99 & 0.99 & $\begin{array}{c}1.54 \\
(0.52)\end{array}$ & 0.004 & 0.007 & $\begin{array}{l}1.53 \\
(0.36)\end{array}$ & $<0.001$ & $<0.001$ \\
\hline $\mathrm{BV}(\mathrm{ml})$ & 96 & $\begin{array}{l}-3.18 \\
(0.62)\end{array}$ & $<0.001$ & $<0.001$ & $\begin{array}{l}-52.2 \\
(24.4)\end{array}$ & 0.035 & 0.046 & $\begin{array}{l}-86.8 \\
(28.6)\end{array}$ & 0.003 & 0.007 & $\begin{array}{l}-34.7 \\
(19.6)\end{array}$ & 0.08 & 0.09 \\
\hline \multicolumn{14}{|c|}{ Mitochondria } \\
\hline CS * & 103 & $\begin{array}{l}-0.026 \\
(0.006)\end{array}$ & $<0.001$ & $<0.001$ & $\begin{array}{l}-0.46 \\
(0.24)\end{array}$ & 0.06 & 0.18 & $\begin{array}{l}-0.30 \\
(0.23)\end{array}$ & 0.20 & 0.39 & $\begin{array}{c}0.16 \\
(0.22)\end{array}$ & 0.45 & 0.61 \\
\hline $\begin{array}{l}\text { NADH-dep. } \\
\text { ATP prod. * }\end{array}$ & 102 & $\begin{array}{l}-0.021 \\
(0.006)\end{array}$ & 0.001 & 0.008 & $\begin{array}{l}-0.47 \\
(0.23)\end{array}$ & 0.045 & 0.16 & $\begin{array}{l}-0.25 \\
(0.22)\end{array}$ & 0.26 & 0.46 & $\begin{array}{c}0.22 \\
(0.21)\end{array}$ & 0.30 & 0.47 \\
\hline $\begin{array}{l}\text { FADH }_{2} \text {-dep. } \\
\text { ATP prod. * }\end{array}$ & 103 & $\begin{array}{l}-0.027 \\
(0.006)\end{array}$ & $<0.001$ & 0.001 & $\begin{array}{l}-0.57 \\
(0.24)\end{array}$ & 0.020 & 0.10 & $\begin{array}{l}-0.55 \\
(0.23)\end{array}$ & 0.020 & 0.10 & $\begin{array}{c}0.03 \\
(0.22)\end{array}$ & 0.91 & 0.94 \\
\hline $\mathrm{GP} *$ & 97 & $\begin{array}{l}-0.032 \\
(0.007)\end{array}$ & $<0.001$ & $<0.001$ & $\begin{array}{l}-0.62 \\
(0.28)\end{array}$ & 0.029 & 0.12 & $\begin{array}{l}0.012 \\
(0.27)\end{array}$ & 0.97 & 0.97 & $\begin{array}{c}0.64 \\
(0.26)\end{array}$ & 0.016 & 0.10 \\
\hline $\mathrm{CCO}^{*}$ & 102 & $\begin{array}{l}-0.035 \\
(0.008)\end{array}$ & $<0.001$ & $<0.001$ & $\begin{array}{l}-0.22 \\
(0.21)\end{array}$ & 0.31 & 0.47 & $\begin{array}{l}-0.44 \\
(0.22)\end{array}$ & 0.051 & 0.17 & $\begin{array}{l}-0.22 \\
(0.21)\end{array}$ & 0.20 & 0.39 \\
\hline Basal * & 95 & $\begin{array}{l}-0.031 \\
(0.008)\end{array}$ & $<0.001$ & $<0.001$ & $\begin{array}{l}-0.52 \\
(0.30)\end{array}$ & 0.08 & 0.23 & $\begin{array}{l}-0.17 \\
(0.29)\end{array}$ & 0.55 & 0.68 & $\begin{array}{c}0.35 \\
(0.27)\end{array}$ & 0.19 & 0.39 \\
\hline $\mathrm{RCRu}$ * & 95 & $\begin{array}{l}-0.003 \\
(0.005)\end{array}$ & 0.51 & 0.65 & $\begin{array}{l}-0.27 \\
(0.18)\end{array}$ & 0.14 & 0.35 & $\begin{array}{l}-0.38 \\
(0.18)\end{array}$ & 0.03 & 0.13 & $\begin{array}{l}-0.11 \\
(0.16)\end{array}$ & 0.49 & 0.64 \\
\hline SRC * & 95 & $\begin{array}{c}0 \\
(0.004)\end{array}$ & 0.92 & 0.94 & $\begin{array}{c}0.03 \\
(0.16)\end{array}$ & 0.85 & 0.93 & $\begin{array}{l}-0.14 \\
(0.15)\end{array}$ & 0.35 & 0.51 & $\begin{array}{l}-0.17 \\
(0.14)\end{array}$ & 0.22 & 0.41 \\
\hline PL/ROS * & 95 & $\begin{array}{c}0.001 \\
(0.005)\end{array}$ & 0.88 & 0.94 & $\begin{array}{c}0.27 \\
(0.20)\end{array}$ & 0.19 & 0.39 & $\begin{array}{c}0.31 \\
(0.20)\end{array}$ & 0.12 & 0.33 & $\begin{array}{c}0.04 \\
(0.18)\end{array}$ & 0.83 & 0.93 \\
\hline IRC & 95 & $\begin{array}{c}0.001 \\
(0.003)\end{array}$ & 0.69 & 0.79 & $\begin{array}{l}-0.09 \\
(0.10)\end{array}$ & 0.35 & 0.51 & $\begin{array}{l}-0.13 \\
(0.10)\end{array}$ & 0.16 & 0.38 & $\begin{array}{l}-0.04 \\
(0.09)\end{array}$ & 0.64 & 0.75 \\
\hline RCR & 95 & $\begin{array}{l}-0.006 \\
(0.007)\end{array}$ & 0.38 & 0.53 & $\begin{array}{l}-0.30 \\
(0.29)\end{array}$ & 0.30 & 0.47 & $\begin{array}{l}-0.43 \\
(0.28)\end{array}$ & 0.13 & 0.33 & $\begin{array}{l}-0.13 \\
(0.26)\end{array}$ & 0.62 & 0.75 \\
\hline
\end{tabular}

In bold, significant with FDR $\leq 0.10$. BV, brain volume; WMHV, white matter hyperintensity volume; CS, citrate synthase; NADH-dep. ATP prod., NADH-dependent ATP production; $\mathrm{FADH}_{2}$-dep. ATP prod., $\mathrm{FADH}_{2}$-dependent ATP production; GP, $\alpha$-glycerophosphatesustained ATP production; CCO, cytochrome $c$ oxidase; basal, glucose-Gln-sustained ATP production; RCRu, respiratory control ratio under uncoupling conditions; SRC, spare respiratory capacity; PL/ROS, proton leak/reactive oxygen species; IRC, index of respiratory capacity; RCR, respiratory control ratio. ${ }^{*}$, indicates the application of log-transformation prior to statistical analysis. ${ }^{* *}$, presents contrast coefficients of the group comparisons in the regression models. 
A. Brain WMH volume

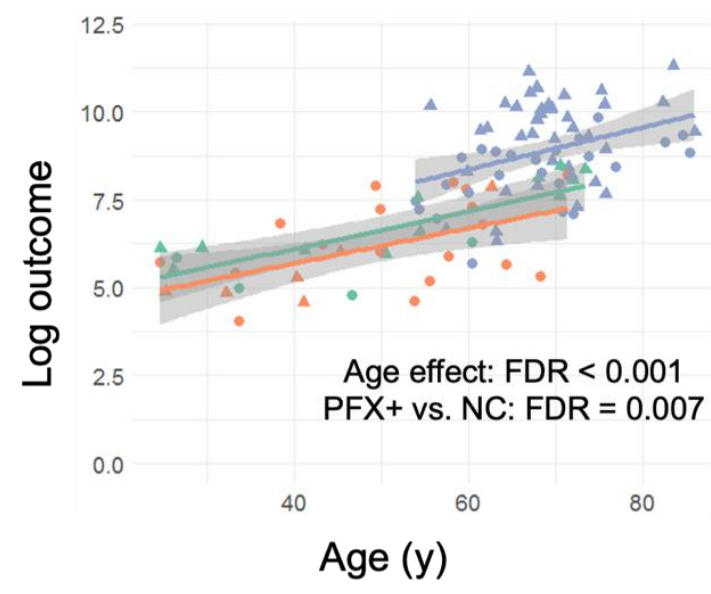

\section{B. Brain volume}

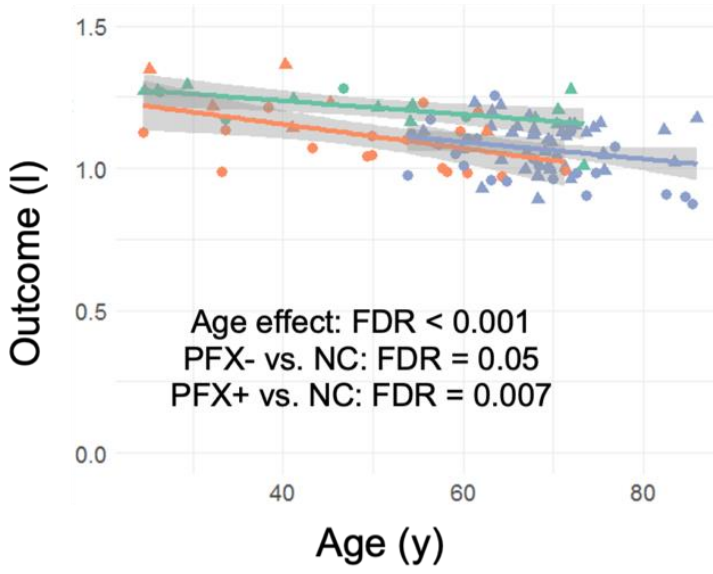

\section{Mitochondrial ATP production by PBMCs}
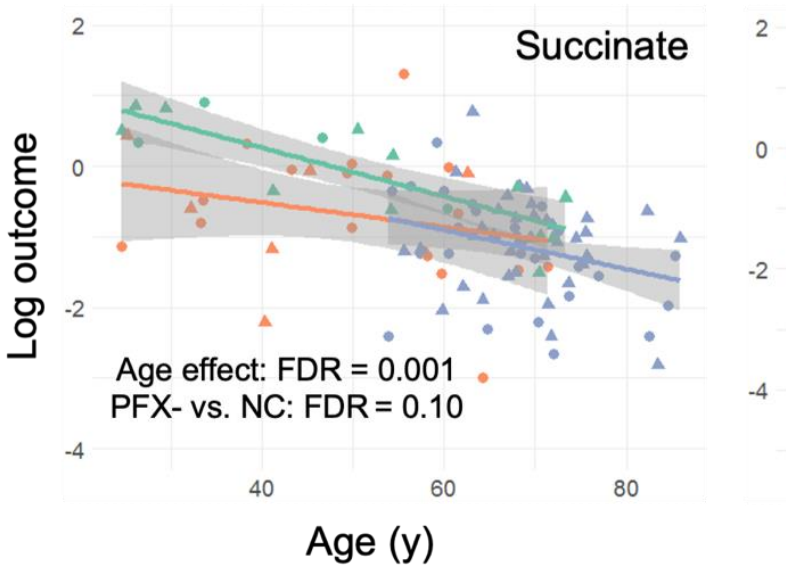

2 Glycerophosphate

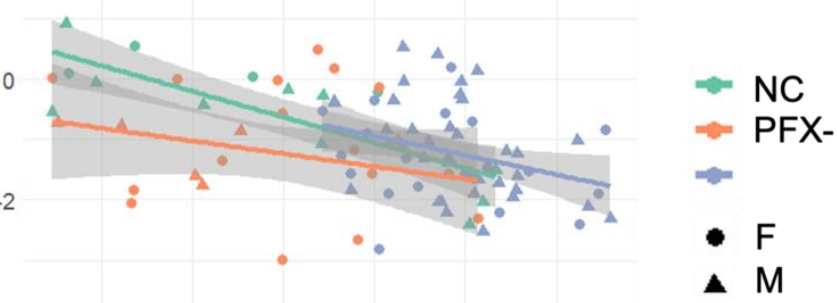

-4 Age effect: FDR $<0.001$

$\begin{array}{lll}40 & 60 & 80\end{array}$

Age (y)

Figure 1. Group differences and correlations between age, brain volumes and mitochondrial outcomes in premutation carriers at FXTAS stages 0 and 1 (PFX-), FXTAS stages 2-5 (PFX+), and non-carriers (NC) (A) White matter hyperintensity (WMH) volume. (B) Whole brain volume. (C) Peripheral mitochondrial ATP production by PBMCs sustained by succinate (left panel) and glycerophosphate (right panel).

2.4. Age-Dependent Negative Correlation between WMHV and Oxygen-Linked ATP Production, and Positive Correlation between Brain Volume and ATP Production and Mitochondrial Mass in the Premutation Carriers

Semi-partial correlations between mitochondrial outcomes and MRI data (while controlling for cranial size) were tested in the cohort constituted by the 87 premutation carriers. Among the 11 mitochondrial outcomes, ATP production fueled by succinate and glucoseglutamine showed significant negative correlations with brain $\mathrm{WMHV}\left(\mathrm{FADH}_{2}\right.$-dependent oxygen consumption/basal $\mathrm{r}=-0.26 /-0.33, \mathrm{FDR}=0.08 / 0.03$ ). Both $\mathrm{FADH}_{2}$-dependent ATP production and markers of mitochondrial mass, namely citrate synthase and Complex IV activities, were correlated positively with BV $(r=0.25-0.32$, FDR $=0.03-0.08$; Table 2, Figure 2). More importantly, no differences with sex were observed. When age was included as a covariate, all correlations between mitochondrial outcomes and MRI data were no longer significant, indicating age as the main driver of the correlations between MRI findings and peripheral mitochondrial outcomes. 
Table 2. Semi-partial correlations between mitochondrial outcomes and volumes of WMHs and whole brain in premutation carriers controlling cranial size in MRI data.

\begin{tabular}{|c|c|c|c|c|c|c|c|c|}
\hline Mitochondrial Outcomes & $N$ & Semi-Partial $r$ & $P$ & FDR & $N$ & Semi-Partial $r$ & $P$ & FDR \\
\hline \multicolumn{5}{|c|}{ With log white matter hyperintensity volume } & \multicolumn{4}{|c|}{ With whole brain volume } \\
\hline Citrate synthase activity * & 87 & -0.227 & 0.036 & 0.13 & 87 & 0.249 & 0.021 & 0.08 \\
\hline NADH-linked ATP production * & 86 & -0.172 & 0.115 & 0.25 & 86 & 0.158 & 0.149 & 0.33 \\
\hline $\mathrm{FADH}_{2}$-linked ATP production * & 87 & -0.264 & 0.014 & 0.08 & 87 & 0.246 & 0.023 & 0.08 \\
\hline $\begin{array}{l}\text { Glycerophosphate-linked ATP } \\
\text { production * }\end{array}$ & 79 & -0.091 & 0.427 & 0.67 & 79 & 0.064 & 0.576 & 0.63 \\
\hline Cytochrome oxidase activity * & 86 & -0.176 & 0.107 & 0.25 & 86 & 0.323 & 0.003 & 0.03 \\
\hline $\begin{array}{l}\text { Glucose-Gln-fueled ATP } \\
\text { production * }\end{array}$ & 81 & -0.330 & 0.003 & 0.03 & 81 & 0.213 & 0.058 & 0.16 \\
\hline $\mathrm{RCRu}^{*}$ & 81 & -0.023 & 0.842 & 0.84 & 81 & 0.098 & 0.385 & 0.61 \\
\hline SRC * & 81 & -0.105 & 0.354 & 0.65 & 81 & 0.020 & 0.862 & 0.86 \\
\hline $\mathrm{PL} / \mathrm{ROS}$ * & 81 & -0.040 & 0.727 & 0.84 & 81 & -0.070 & 0.540 & 0.63 \\
\hline IRC & 81 & 0.026 & 0.819 & 0.84 & 81 & 0.082 & 0.470 & 0.63 \\
\hline RCR & 81 & -0.060 & 0.599 & 0.82 & 81 & 0.135 & 0.231 & 0.42 \\
\hline
\end{tabular}

In bold, FDR $\leq 0.10 .{ }^{*}$, indicates the application of log-transformation prior to statistical analysis. Abbreviations: see under Table 1.

\section{A. WMH volume and mitochondrial ATP production}

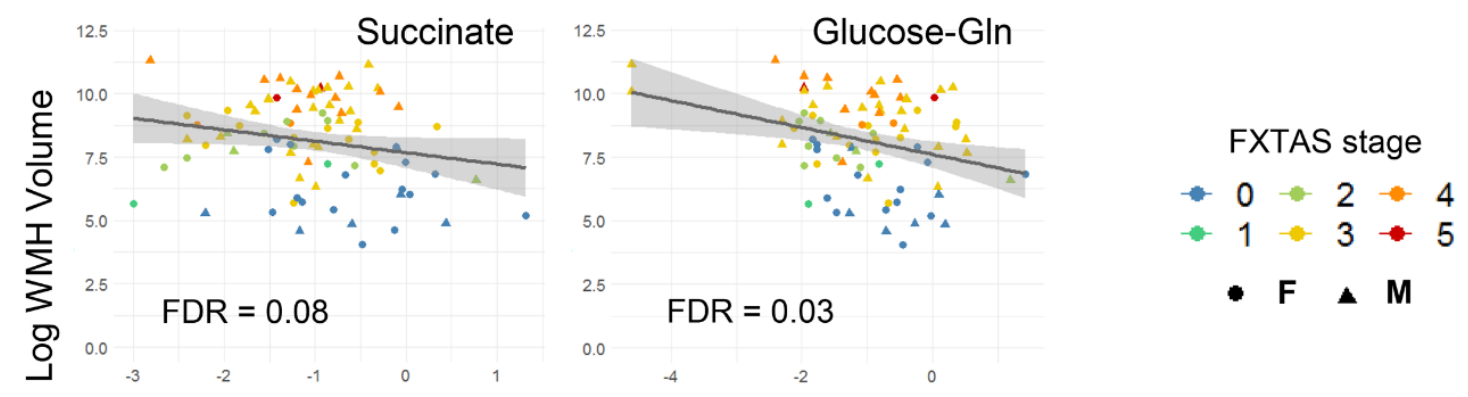

Log ATP production

\section{B. Brain volume and mitochondrial ATP production and mass}
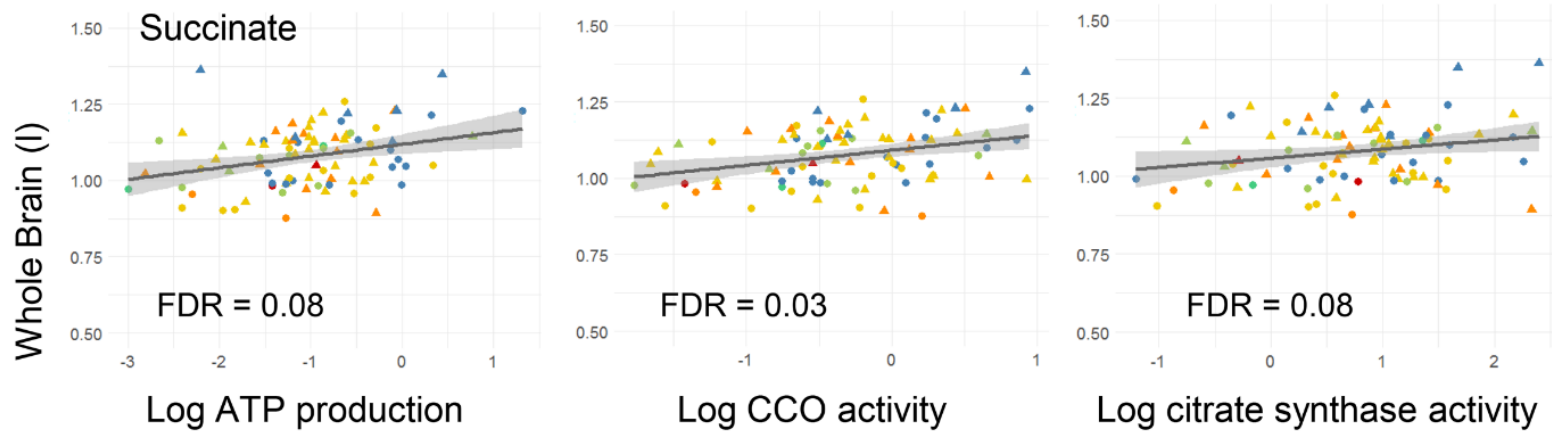

Figure 2. Correlation between peripheral mitochondrial outcomes and volumes of WMHs and whole brain in premutation carriers. (A) Correlations between WMHV and mitochondrial ATP production sustained by succinate (left panel) and glucose-Gln (right panel). (B) Correlations between whole brain volume and mitochondrial ATP production sustained by succinate and mitochondrial mass (CCO and citrate synthase activities). Two outliers for glucose-Gln sustained ATP production and one outlier for CCO activity (with very small values) were removed from the analyses. CCO, cytochrome $c$ oxidase. 
Consistent with the above results, and with the premise that age is considered the greatest risk factor in neurodegenerative disorders [1-3] and FXTAS mainly affects premutation carriers older than 50 years, the correlations between FXTAS stage (as proxy for the impact of tremor and ataxia has on daily activities [61]) and MRI/mitochondrial measurements were analyzed with only those carriers aged $50 \mathrm{y}$ and above $(\mathrm{N}=74,40$ males, 34 females). In agreement with the concept that increases in WMHV are core features of FXTAS pointing to cumulative brain damage, only WMHV, adjusted for age, sex, and cranial size, showed a significant correlation with FXTAS stage $(\beta=0.42 \pm 0.097, p<0.001$; Figure 3). None of the mitochondrial outcomes or BV showed significant correlations with FXTAS stage $(p>0.15$; Supplementary Table S1).
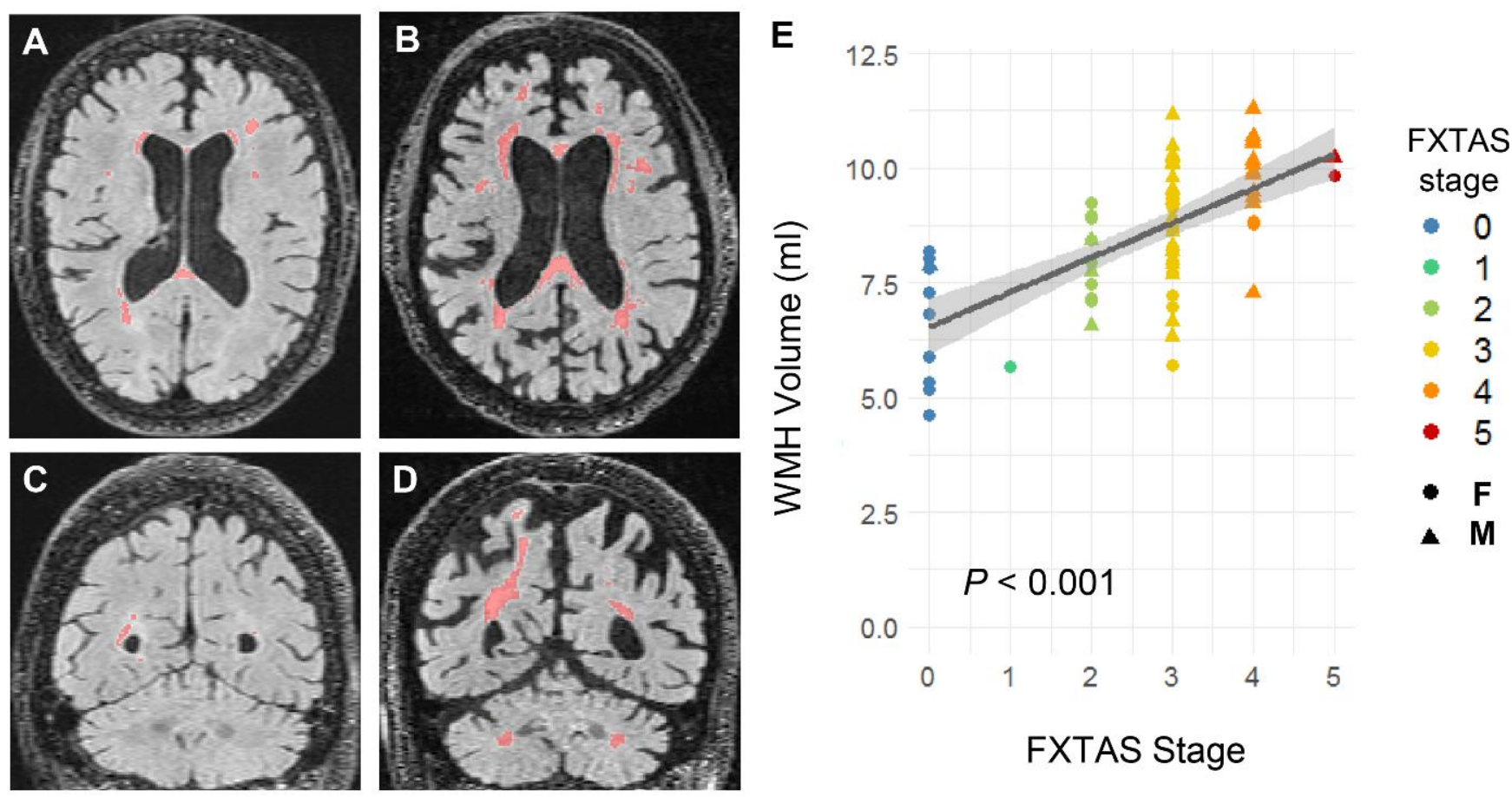

FXTAS Stage

Figure 3. WMH quantifications and correlation with FXTAS stage. (A) Representative axial view of the FLAIR image showing WMHs in the periventricular regions and deep white matter for a 68-y-old female carrier at FXTAS stage 3. (B) Representative axial view of the FLAIR image showing more extensive WMHs in the periventricular regions and deep white matter for a 69-y-old male carrier at FXTAS stage 3 relative to the female carrier shown in panel (A). (C) A coronal view of the FLAIR image showing periventricular WMHs at the posterior horn of the lateral ventricles for the same female carrier as it is in (A). (D) A coronal view of the FLAIR image showing periventricular WMHs extending to the white matter in the right parietal lobe as well as bilateral WMHs in the middle cerebellar peduncle in the same male carrier as in (B).

(E) Correlation between WMHV and FXTAS stage in male and female carriers aged 50 years and older.

\section{Discussion}

WMHs in the middle cerebellar peduncle and cerebral white matter, along with generalized brain atrophy, are core radiological features of FXTAS and, as such, used as criteria for FXTAS diagnosis $[62,63]$. Mitochondrial dysfunction, demonstrated in several biological samples of premutation carriers with and without FXTAS, has been recognized as an early marker of FMR1 premutation even without overt signs of clinical symptoms $[18,19,21,22,64]$. Here, for the first time, we examined the putative correlations of WMHV and BV with several outcomes of peripheral mitochondrial bioenergetics between FMR1 premutation carriers and non-carriers in a relatively large cohort (87 carriers vs. 16 non-carriers).

In the context of MRI findings, both WMHV and BV correlated with FXTAS morbidity as WMHV was significantly higher and whole BV was lower in PFX+ (at FXTAS stages $\geq 2$ ) 
compared with both PFX- (at FXTAS stages $\leq 1$ ) and non-carriers (after adjusting for age, sex, and cranial size; FDR < 0.001-0.09). Only BV was smaller in PFX- (FDR = 0.05) compared with non-carriers (Table 2, Figure 1B). The smaller BV in PFX-relative to noncarriers is consistent with our previous cross-sectional study using a larger dataset of males (142 non-carriers and 109 PFX, aged 8-81 years), which reported accelerated BV decrease in PFX - compared with non-carriers [65]. We also showed significant changes in WMHV and BV with age across all participants (FDR < 0.001) in agreement with other studies [66-70].

WMHV was also lower in females than males $(\mathrm{FDR}=0.01)$ regardless of the premutation status. However, in a post-hoc analysis including only premutation carriers, this significance was no longer observed after adding FXTAS stage as a covariate, suggesting that WMHV is mainly impacted by FXTAS progression. These findings are consistent with an early study that reported increased WMHV in PFX+ compared with both PFXand non-carriers of the same sex but, contrary to our findings, no differences in WMHV were identified between sexes [71]. This discrepancy may originate from the uneven sex distribution of carriers across FXTAS stages, females being more numerous than males at lower FXTAS stages (75\% females vs. $25 \%$ males at stages 0 and 1 ) and males being more numerous than females at higher FXTAS stages $(11.5 \%$ females vs. $88.5 \%$ males at stages 4 and 5).

In contrast to the lack of significant differences recorded for WMHV in PFX - compared with non-carriers, PFX - and PFX+, both showed lower peripheral oxygen-linked ATP production sustained by succinate than non-carriers after age-adjustment (Table 1). Furthermore, within the premutation carriers, PFX+ exhibited higher oxygen-linked ATP production fueled by glycerophosphate than PFX - after age-adjustment (Table 1). These results may have two significant biological implications. First, it is possible that peripheral changes in mitochondrial bioenergetics associated with FMR1 premutation are early changes of the disease that precede the development of WMHs in the brain and continue to accompany not only the onset but also the progression of FXTAS. This is consistent with the deficits in oxidative phosphorylation and reduced glucose metabolism shown as early pathological alterations in Alzheimer's disease, another neurodegenerative condition $[25,26]$. Secondly, some of the subjects at higher FXTAS stages may be increasing the flux of fatty acids to offset the decline in ATP levels or production and/or overcome a deficit in the malate-aspartate shuttle. Although the higher values of oxygen-linked ATP production fueled by glycerophosphate by the PFX+ group compared with PFX - might seem beneficial, the fact that not all electron transport chain segments' activities follow the same direction of change is more indicative of an altered protein handling (proteotoxicity), which is associated with impaired mitochondria-nuclear crosstalk [72] and mitochondrial unfolded protein response [73]. In addition, while in most tissues (including PBMCs) deficits in glucose metabolism via pyruvate dehydrogenase can be tolerated by utilizing other substrates to provide energy (e.g., glycerophosphate), this up-regulation might not improve brain energy homeostasis as fatty-acid oxidation in this organ is negligible [74,75].

The observation of a significant age-dependent decline in citrate synthase activity in PBMCs across carriers and non-carriers agrees with one of our earlier studies performed with a smaller number of participants (30 premutation carriers vs. $12 \mathrm{NCs}$; [23]). It is also consistent with another study showing a clear drop in citrate synthase activity in PBMCs between 16 and 20 and 46 and 55 years of age, remaining at a low, constant value through 66-89 years of age [76]. While in non-carriers the decrease in citrate synthase activity was mirrored by a decline in Complex IV activity (Spearman $r=0.6002, p=0.0031$ ) pointing to an overall decline in mitochondrial mass, no statistically significant correlation was observed between these outcomes in carriers (Spearman $r=0.1912$ and $0.1040, p=0.1542$ and 0.2584 respectively for carriers without FXTAS and with FXTAS), suggesting a shrinkage of the mitochondrial matrix (or the TCA cycle) with respect to the electron transport chain.

Importantly, peripheral mitochondrial ATP production fueled by succinate or glucoseglutamine correlated negatively with brain WMHV (semi-partial $r=-0.26$ and -0.33 , FDR $=0.03-0.08)$, and mitochondrial mass and succinate-fueled oxygen-linked ATP pro- 
duction correlated positively with BV (semi-partial $r=0.25-0.32$, FDR $=0.03-0.08$ ) when combining all premutation carriers (Table 2, Figure 2A,B). However, these correlations were no longer significant when age was included as a covariate implicating a critical role for age in mediating the associations between brain imaging findings and peripheral mitochondrial outcomes. This model also suggests that in patients with FXTAS, the decline in bioenergetics (function) is maintained across stages preceding the development of more detrimental phenotypes as indicated above.

The question of whether peripheral bioenergetic changes may reflect or be predictive of CNS mitochondrial deficits with links to WMHV and BV changes deserves a separate discussion. There is a clear overlap of features between premutation phenotype and mitochondrial diseases, including WMHs in both cerebral and cerebellar white matter in mitochondrial diseases and FXTAS $[62,77,78]$. Cerebellar atrophy, particularly affecting children, is another core feature of mitochondrial dysfunction [77]. Consistently, we have reported abnormal developmental trajectory of cerebellar volume in PFX - aged 8 to 81 years and significant cerebellar atrophy in PFX+ compared with both PFX - and NCs [65]. However, WMHs have not been observed in children with the premutation, suggesting that the detrimental effect of mitochondrial bioenergetic changes on the central nervous system (CNS) may not be as severe in children with the premutation relatively to children with mitochondrial disorders. However, both conditions (mitochondrial disorders and FXTAS) are clearly associated with energy deficits and cellular oxidative damage from reactive oxygen species [46]. Nonetheless, the current study provides direct evidence linking CNS imaging changes associated with the premutation phenotype represented by white matter damage and brain atrophy and reduced peripheral mitochondrial mass and ATP production. At the mechanistic level, our findings of mitochondrial dysfunction in the premutation may be explained by recent reports on fragile $X$ syndrome's models (contrary to the premutation, there is no detectable FMR1 gene or FMRP protein expression in males and reduced FMRP expression in females), in which FMRP was found to regulate mitochondrial mRNA expression and energy homeostasis (murine model), and energy metabolism and mitochondrial function (Drosophila model) [79,80]. A recent study by our team provides further support for proteotoxicity and altered unfolded protein response at the core of the bioenergetic deficits in FXTAS [18,22,81,82], as sulforaphane-mediated normalization of these processes recovered mitochondrial function [82].

\section{Materials and Methods}

\subsection{Research Participants}

We included adults who participated in the genotype-phenotype study of families with fragile X from 2013 through 2019 with the availabilities of both MRI and blood samples (except for 7 non-carriers who did not undergo MRI). Written informed consent was obtained from all participants before participation in line with the Declaration of Helsinki. The study was approved by the Institutional Review Board of the University of California Davis Medical Center (Genotype-Phenotype Relationships in Fragile X Families, IRB Number 254134) and all methods were performed in accordance with their guidelines and regulations. FXTAS stage was scored by a trained physician (RJH) based on the severity of movement and gait impairments (stage 1: subtle or questionable signs, stages 2-6: clear tremor/balance problems with minor to severe interference of daily living) [61]. Premutation carriers at FXTAS stages $\leq 1$ were combined into the non-FXTAS group (PFX-) whereas those at FXTAS stages $\geq 2$ formed the FXTAS group (PFX+).

\subsection{PBMCs Preparation}

Blood (5-7 mL) was collected in BD Vacutainer Cell Preparation Tubes ${ }^{\mathrm{TM}}$ (BectonDickinson, Franklin Lakes, NJ, USA) and processed according to the manufacturer's recommendation within less than $1 \mathrm{~h}$ from blood collection. Most samples were collected between 9 and 11 a.m. Lymphocytes were isolated as previously described [22]. 


\subsection{Mitochondrial Outcomes}

Chemicals and biochemicals: EDTA, EGTA, sodium succinate, mannitol, sucrose, and HEPES were all purchased from Sigma (St. Louis, MO, USA). Tris-HCl, glycine, sodium chloride, and potassium chloride were purchased from Fisher (Pittsburg, PA, USA). Bovine serum albumin (fatty-acid free) was obtained from MP Biomedicals. All other reagents were of analytical or higher grade.

For polarographic determination of ATP-linked oxygen uptake of intact or permeabilized cells, we used a set-up of two Clark-type oxygen electrodes with two chambers $[21,24,64,83-88]$. The semipermeable membrane is changed the day before the experiment is planned to avoid unwanted cell debris that may have become attached to it. The membrane is hydrated a day before (for no less than $8 \mathrm{~h}$ ) to facilitate oxygen diffusion. Washes of the chamber are done with $70 \%$ ethanol, and 3 washes of dd water. The calibration of the electrode entails the recording of zero oxygen concentration (with dithionite) and air-saturate solution (used for functional studies) warmed up at the temperature at which the experiments are run. The calibration is run in duplicates with $<10 \% \mathrm{CV}$. The oxygen concentration in the calibrating solution is calculated with the atmospheric pressure (barometer) and ambient temperature (thermometer). Additions to the chamber are done by using Hamilton syringes to avoid increasing oxygen concentrations throughout the evaluations. The chamber is constantly stirred with a Teflon-coated minibar to ensure a homogenous diffusion of substrates and oxygen. Washes with $70 \%$ ethanol are warranted after using rotenone, antimycin or FCCP, which tend to stick to the plastic walls of the chamber. ATP-driven oxygen uptake is usually done in duplicates at a given cell concentration (which was calculated before starting this protocol). All enzymatic assays are performed within the hour of collecting the blood sample and run in parallel with controls. Reproducibility is ensured by running a subset of samples previously tested in parallel with new batches of samples.

Activities of Complexes I-V in digitonin-permeabilized lymphocytes were determined by polarography essentially as described before [22,88]. Briefly, an aliquot $\left(1.0-2.0 \times 10^{6}\right)$ of lymphocytes was added to the chamber equipped with a Clark-type Hansatech oxygen electrode at $20-22{ }^{\circ} \mathrm{C}$ in $0.3 \mathrm{~mL}$ of buffer containing $0.22 \mathrm{M}$ sucrose, $50 \mathrm{mM} \mathrm{KCl}, 1 \mathrm{mM}$ EDTA, $10 \mathrm{mM} \mathrm{KH}_{2} \mathrm{PO}_{4}$, and $10 \mathrm{mM}$ HEPES, $\mathrm{pH}$ 7.4. Oxygen consumption rates were evaluated in air-saturated solutions in the presence of (i) $1 \mathrm{mM}$ ADP plus $1 \mathrm{mM}$ malate$10 \mathrm{mM}$ glutamate followed by the addition of $5 \mu \mathrm{M}$ rotenone; (ii) $10 \mathrm{mM}$ succinate followed by the addition of $1 \mathrm{mM}$ malonate; (iii) $1 \mathrm{mM} \alpha$-glycerophosphate followed by the addition of $3.6 \mu \mathrm{M}$ antimycin A; and (iv) $10 \mathrm{mM}$ ascorbate and $0.2 \mathrm{mM} \mathrm{N}, N, N^{\prime}, N^{\prime}$-tetramethyl$p$-phenylenediamine followed by the addition of $1 \mathrm{mM} \mathrm{KCN}$ (activity of Complex IV). Activities of individual electron transport chain (ETC) segments were evaluated as the difference of oxygen uptake recorded before and after the addition of specific inhibitors. Most mitochondrial inhibitors and uncouplers were stored at $-80{ }^{\circ} \mathrm{C}$ as concentrated stock solutions (high $\mathrm{mM}$ ) in DMSO to prevent unwanted oxidation or degradation. Quality control checks were performed with beef heart submitochondrial particles and results were compared to data collected over the years.

Oxygen consumption was also evaluated in intact cells using a Clark-type oxygen electrode (Hansatech, King's Lynn, UK) as previously described [23,89]. ATP-linked oxygen uptake (or State-3-dependent oxygen uptake) was calculated as the difference between basal and oligomycin-induced State 4 oxygen uptake rates; State 4o is the residual respiration after inhibition of ATP synthesis with the ATPase-specific inhibitor $0.2 \mu \mathrm{M}$ oligomycin; maximal respiratory capacity, or State $3 \mathrm{u}$, is described as the oxygen uptake rate in the presence of $2 \mu \mathrm{M}$ of the uncoupler carbonyl cyanide-4-(trifluoromethoxy) phenylhydrazone (FCCP); respiratory control ratio (RCR) was calculated as the ratio between States 3 and 4o; index of respiratory capacity (IRC) was calculated as the difference between State 3 and State 40 normalized by that of State 3u. Mitochondrial proton leak (PL)/ROS production was calculated from the oligomycin-resistant oxygen consumption rates and normalized by basal respiration in the presence of $10 \mathrm{mM}$ glucose- $2 \mathrm{mM}$ glutamine in RPMI- 1640 . 
Citrate synthase activity was evaluated spectrophotometrically with a Tecan Infinite M200 microplate reader at $412 \mathrm{~nm}$ as described before by using 2.5 to $3 \times 10^{5}$ cells [22]. All cell pellets destined for this activity were tested within the hour of blood extraction. If stored, the pellets were supplemented with proteolytic inhibitors (4-benzenesulfonyl fluoride hydrochloride, EDTA, bestatin, E-64, leupeptin, aprotinin, from Sigma) and kinase and phosphatase inhibitors (sodium orthovanadate, sodium molybdate, sodium tartrate, imidazole, cantharidin, (-)p-bromolevamisole oxalate, calyculin A, from Sigma) and stored at $-80{ }^{\circ} \mathrm{C}$.

\subsection{MRI Acquisition and Processing}

MRI scans were acquired on a Siemens Trio 3T MRI scanner equipped with a 32channel head coil (Siemens Medical Solutions, Erlangen, Germany). One-millimeter isotropic T1-weighted scans were collected covering the whole brain using the magnetization prepared rapid gradient-echo (MPRAGE) sequence in 192 sagittal slices with repetition time (TR) of $2170 \mathrm{~ms}$, echo time (TE) of $4.82 \mathrm{~ms}$, and $7^{\circ}$ flip angle. Fluid attenuated inversion recovery (FLAIR) images for quantifying WMHV were acquired in 104 sagittal slices of $1.9-\mathrm{mm}$ thickness with an in-plane resolution of $0.47 \mathrm{~mm}^{2}$, TR of $5000 \mathrm{~ms}$, TE of $456 \mathrm{~ms}$, and inversion time $1700 \mathrm{~ms}$.

Both T1 and FLAIR scans were corrected for intensity inhomogeneities due to MRI bias field using N4 [90]. BV and brain scaling factor (for correcting individual differences in cranial size) were obtained on MPRAGE scans using the SIENAX program [91] from FSL. Optimal values were obtained by adjusting the parameter used for brain extraction. WMHV was quantified on FLAIR images using lesion prediction algorithm from SPM12 [92]. Lesion masks were generated by setting appropriate thresholds on lesion probability maps using the FSL command, fslmaths, followed by manual correction for errors using ITK-Snap [93]. WMHV calculations were performed using the FSL command, fslstats.

\subsection{Statistical Analysis}

All statistical analyses were conducted in the open-source statistical package R 3.6.3 (http:/ / www.r-project.org/ accessed on 25 June 2020). Multiple linear regression was used to study the effects of age, group, sex, and age-by-group interaction on individual $\mathrm{MRI} /$ mitochondrial outcomes. Contrasts were used to make specific group comparisons within a regression model. WMHV and most mitochondrial outcomes (except the index of respiratory capacity and respiratory control ratio; IRC and RCR) did not follow normal distributions in premutation carriers. Consequently, log-transformation was applied to these variables before performing any statistical analyses. Since FXTAS commonly occurs in premutation carriers aged 50 and above, the correlations between FXTAS stage and $\mathrm{MRI} /$ mitochondrial outcomes were analyzed including only the premutation carriers older than 50 years, while controlling for age and sex. Brain scaling factor was added as a covariate for all statistical models involving the MRI data. Model selection procedure was carried out using a stepwise approach via the likelihood ratio test. The correlations between MRI and mitochondrial measurements were examined in all premutation carriers. Semi-partial correlation coefficients from the R package "ppcor" were employed to assess the associations between individual mitochondrial outcomes and individual MRI measures while controlling cranial size for MRI measures only. The Benjamini-Hochberg method of false discovery rate (FDR) [94] was applied to control the FDR at $10 \%$ for all hypotheses tested in one type of analysis.

Supplementary Materials: The following are available online at https:/ / www.mdpi.com/article/10 .3390/ijms22179171/s1.

Author Contributions: J.Y.W., conceptualization, generation of brain imaging data, statistical analysis, manuscript writing, and review and critique of the manuscript; E.N., execution, evaluation of PBMC's bioenergetics, manuscript writing, and review and critique of the manuscript; K.K., supervision of statistical analysis, interpretation of results, and review and critique of the manuscript; Y.A.M., 
data gathering, execution of the research project, and review and critique of the manuscript; R.J.H., conceptualization, organization of the research project, and review and critique of the manuscript; C.G., conceptualization, organization, execution of the research project, manuscript writing, and review and critique of the manuscript. All authors have read and agreed to the published version of the manuscript.

Funding: This research was supported by NICHD (HD 036071) and the MIND Institute Intellectual and Developmental Disabilities Research Center (IDDRC) (P50 HD103526).

Institutional Review Board Statement: The study was conducted according to the guidelines of the Declaration of Helsinki, and it was approved by the Institutional Review Board of the University of California Davis Medical Center (Genotype-Phenotype Relationships in Fragile X Families, IRB Number 254134). All methods were performed in accordance with their guidelines and regulations.

Informed Consent Statement: Written informed consent was obtained from all participants before participation in line with the Declaration of Helsinki.

Data Availability Statement: Data presented in this study are contained within the article or Supplementary Material.

Acknowledgments: We thank the participants and their families for their dedication and support for this research.

Conflicts of Interest: R.J.H. received funding from Zynerba, Ovid and the Azrieli Foundation for carrying out treatment studies in patients with fragile $X$ syndrome (FXS). She also consulted with Fulcrum, Ovid and Zynerba regarding treatment studies in individuals with FXS. The funders had no role in study design, data collection, analysis, data interpretation, or manuscript writing. All other authors report neither biomedical nor financial interests or any other potential conflicts of interest.

\section{References}

1. Bickford, P.C.; Flowers, A.; Grimmig, B. Aging leads to altered microglial function that reduces brain resiliency increasing vulnerability to neurodegenerative diseases. Exp. Gerontol. 2017, 94, 4-8. [CrossRef]

2. Ishii, R.; Canuet, L.; Aoki, Y.; Hata, M.; Iwase, M.; Ikeda, S.; Nishida, K.; Ikeda, M. Healthy and Pathological Brain Aging: From the Perspective of Oscillations, Functional Connectivity, and Signal Complexity. Neuropsychobiology 2017, 75, 151-161. [CrossRef] [PubMed]

3. Jan, A.T.; Azam, M.; Rahman, S.; Almigeiti, A.; Choi, D.H.; Lee, E.J.; Haq, Q.M.R.; Choi, I. Perspective Insights into Disease Progression, Diagnostics, and Therapeutic Approaches in Alzheimer's disease: A Judicious Update. Front. Aging Neurosci. 2017, 9, 356. [CrossRef]

4. Childs, B.G.; Gluscevic, M.; Baker, D.J.; Laberge, R.-M.; Marquess, D.; Dananberg, J.; Van Deursen, J.M. Senescent cells: An emerging target for diseases of ageing. Nat. Rev. Drug Discov. 2017, 16, 718-735. [CrossRef]

5. Wallace, C.D.; Fan, W. Energetics, epigenetics, mitochondrial genetics. Mitochondrion 2010, 10, 12-31. [CrossRef] [PubMed]

6. Wallace, D.C.; Fan, W.; Procaccio, V. Mitochondrial Energetics and Therapeutics. Annu. Rev. Pathol. Mech. Dis. 2010, 5, 297-348. [CrossRef]

7. Wallace, D.C. A mitochondrial bioenergetic etiology of disease. J. Clin. Investig. 2013, 123, 1405-1412. [CrossRef] [PubMed]

8. Bouzier-Sore, A.-K.; Voisin, P.; Bouchaud, V.; Bezancon, E.; Franconi, J.-M.; Pellerin, L. Competition between glucose and lactate as oxidative energy substrates in both neurons and astrocytes: A comparative NMR study. Eur. J. Neurosci. 2006, 24, 1687-1694. [CrossRef] [PubMed]

9. Khatri, N.; Man, H.-Y. Synaptic Activity and Bioenergy Homeostasis: Implications in Brain Trauma and Neurodegenerative Diseases. Front. Neurol. 2013, 4. [CrossRef]

10. Kim, H.A.; Miller, A.A.; Drummond, G.R.; Thrift, A.G.; Arumugam, T.; Phan, T.G.; Srikanth, V.K.; Sobey, C.G. Vascular cognitive impairment and Alzheimer's disease: Role of cerebral hypoperfusion and oxidative stress. Naunyn-Schmiedeberg's Arch. Pharmacol. 2012, 385, 953-959. [CrossRef]

11. Mosconi, L.; Sorbi, S.; De Leon, M.J.; Li, Y.; Nacmias, B.; Myoung, P.S.; Tsui, W.; Ginestroni, A.; Bessi, V.; Fayyazz, M.; et al. Hypometabolism exceeds atrophy in presymptomatic early-onset familial Alzheimer's disease. J. Nucl. Med. 2006, 47, 1778-1786.

12. Ossenkoppele, R.; van der Flier, W.M.; Zwan, M.D.; Adriaanse, S.F.; Boellaard, R.; Windhorst, A.D.; Barkhof, F.; Lammertsma, A.A.; Scheltens, P.; van Berckel, B.N. Differential effect of APOE genotype on amyloid load and glucose metabolism in AD dementia. Neurology 2012, 80, 359-365. [CrossRef]

13. Reiman, E.M.; Caselli, R.J.; Yun, L.S.; Chen, K.; Bandy, D.; Minoshima, S.; Thibodeau, S.N.; Osborne, D. Preclinical evidence of Alzheimer's disease in persons homozygous for the epsilon 4 allele for apolipoprotein E. N. Engl. J. Med. 1996, 334, 752-758. [CrossRef] 
14. Small, G.W.; Mazziotta, J.C.; Collins, M.T.; Baxter, L.R.; Phelps, M.E.; Mandelkern, M.A.; Kaplan, A.; La Rue, A.; Adamson, C.F.; Chang, L.; et al. Apolipoprotein E type 4 allele and cerebral glucose metabolism in relatives at risk for familial Alzheimer disease. JAMA 1995, 273, 942-947. [CrossRef] [PubMed]

15. Chiaravalloti, A.; Martorana, A.; Koch, G.; Toniolo, S.; Di Biagio, D.; Di Pietro, B.; Schillaci, O. Functional correlates of t-Tau, p-Tau and A $31-42$ amyloid cerebrospinal fluid levels in Alzheimer's disease: A 18F-FDG PET/CT study. Nucl. Med. Commun. 2015, 36, 461-468. [CrossRef] [PubMed]

16. Friedland, R.P.; Budinger, T.F.; Ganz, E.; Yano, Y.; Mathis, C.A.; Koss, B.; Ober, B.A.; Huesman, R.H.; Derenzo, S.E. Regional cerebral metabolic alterations in dementia of the Alzheimer type: Positron emission tomography with [18F]fluorodeoxyglucose. J. Comput. Assist. Tomogr. 1983, 7, 590-598. [CrossRef] [PubMed]

17. Minoshima, S.; Giordani, B.; Berent, S.; Frey, K.A.; Foster, N.L.; Kuhl, D.E. Metabolic reduction in the posterior cingulate cortex in very early Alzheimer's disease. Ann. Neurol. 1997, 42, 85-94. [CrossRef] [PubMed]

18. Giulivi, C.; Napoli, E.; Tassone, F.; Halmai, J.; Hagerman, R. Plasma metabolic profile delineates roles for neurodegeneration, pro-inflammatory damage and mitochondrial dysfunction in the FMR1 premutation. Biochem. J. 2016, 473, 3871-3888. [CrossRef]

19. Giulivi, C.; Napoli, E.; Tassone, F.; Halmai, J.; Hagerman, R. Plasma Biomarkers for Monitoring Brain Pathophysiology in FMR1 Premutation Carriers. Front. Mol. Neurosci. 2016, 9, 71. [CrossRef]

20. Napoli, E.; Ross-Inta, C.; Song, G.; Wong, S.; Hagerman, R.; Gane, L.W.; Smilowitz, J.T.; Tassone, F.; Giulivi, C. Premutation in the Fragile X Mental Retardation 1 (FMR1) Gene Affects Maternal Zn-milk and Perinatal Brain Bioenergetics and Scaffolding. Front. Neurosci. 2016, 10, 159. [CrossRef]

21. Napoli, E.; Ross-Inta, C.; Wong, S.; Omanska-Klusek, A.; Barrow, C.; Iwahashi, C.; Garcia-Arocena, D.; Sakaguchi, D.; BerryKravis, E.; Hagerman, R.; et al. Altered zinc transport disrupts mitochondrial protein processing/import in fragile X-associated tremor/ataxia syndrome. Hum. Mol. Genet. 2011, 20, 3079-3092. [CrossRef]

22. Napoli, E.; Song, G.; Schneider, A.; Hagerman, R.; Eldeeb, M.A.A.A.; Azarang, A.; Tassone, F.; Giulivi, C. Warburg effect linked to cognitive-Executive deficits in FMR1 premutation. FASEB J. 2016, 30, 3334-3351. [CrossRef] [PubMed]

23. Napoli, E.; Song, G.; Wong, S.; Hagerman, R.; Giulivi, C. Altered Bioenergetics in Primary Dermal Fibroblasts from Adult Carriers of the FMR1 Premutation Before the Onset of the Neurodegenerative Disease Fragile X-Associated Tremor/Ataxia Syndrome. Cerebellum 2016, 15, 552-564. [CrossRef] [PubMed]

24. Napoli, E.; Wong, S.; Hung, C.; Ross-Inta, C.; Bomdica, P.; Giulivi, C. Defective mitochondrial disulfide relay system, altered mitochondrial morphology and function in Huntington's disease. Hum. Mol. Genet. 2013, 22, 989-1004. [CrossRef] [PubMed]

25. Armand-Ugon, M.; Ansoleaga, B.; Berjaoui, S.; Ferrer, I. Reduced mitochondrial activity is early and steady in the entorhinal cortex but it is mainly unmodified in the frontal cortex in Alzheimer's disease. Curr. Alzheimer Res. 2017, 14, 1327-1334. [CrossRef] [PubMed]

26. Ishii, K.; Sasaki, M.; Kitagaki, H.; Yamaji, S.; Sakamoto, S.; Matsuda, K.; Mori, E. Reduction of cerebellar glucose metabolism in advanced Alzheimer's disease. J. Nucl. Med. 1997, 38, 925-928.

27. Bubber, P.; Haroutunian, V.; Fisch, G.; Blass, J.P.; Gibson, G.E. Mitochondrial abnormalities in Alzheimer brain: Mechanistic implications. Ann. Neurol. 2005, 57, 695-703. [CrossRef] [PubMed]

28. Liu, Y.; Liu, F.; Iqbal, K.; Grundke-Iqbal, I.; Gong, C.-X. Decreased glucose transporters correlate to abnormal hyperphosphorylation of tau in Alzheimer disease. FEBS Lett. 2008, 582, 359-364. [CrossRef] [PubMed]

29. Trimmer, P.A.; Borland, M.K. Differentiated Alzheimer's disease transmitochondrial cybrid cell lines exhibit reduced organelle movement. Antioxid. Redox Signal. 2005, 7, 1101-1109. [CrossRef]

30. Ghosh, D.; LeVault, K.R.; Barnett, A.J.; Brewer, G.J. A reversible early oxidized redox state that precedes macromolecular ROS damage in aging nontransgenic and 3xTg-AD mouse neurons. J. Neurosci. 2012, 32, 5821-5832. [CrossRef]

31. Kitazawa, M.; Cheng, D.; LaFerla, F.M. Chronic copper exposure exacerbates both amyloid and tau pathology and selectively dysregulates cdk5 in a mouse model of AD. J. Neurochem. 2009, 108, 1550-1560. [CrossRef]

32. Smith, M.A.; Sayre, L.M.; Anderson, V.E.; Harris, P.L.; Beal, M.F.; Kowall, N.; Perry, G. Cytochemical Demonstration of Oxidative Damage in Alzheimer Disease by Immunochemical Enhancement of the Carbonyl Reaction with 2,4-Dinitrophenylhydrazine. J. Histochem. Cytochem. 1998, 46, 731-735. [CrossRef] [PubMed]

33. Walls, K.C.; Coskun, P.; Gallegos-Perez, J.-L.; Zadourian, N.; Freude, K.; Rasool, S.; Blurton-Jones, M.; Green, K.N.; LaFerla, F.M. Swedish Alzheimer Mutation Induces Mitochondrial Dysfunction Mediated by HSP60 Mislocalization of Amyloid Precursor Protein (APP) and Beta-Amyloid. J. Biol. Chem. 2012, 287, 30317-30327. [CrossRef] [PubMed]

34. Brownlow, M.L.; Joly-Amado, A.; Azam, S.; Elza, M.; Selenica, M.-L.; Pappas, C.; Small, B.; Engelman, R.; Gordon, M.N.; Morgan, D. Partial rescue of memory deficits induced by calorie restriction in a mouse model of tau deposition. Behav. Brain Res. 2014, 271, 79-88. [CrossRef] [PubMed]

35. Qin, W.; Yang, T.; Ho, L.; Zhao, Z.; Wang, J.; Chen, L.; Zhao, W.; Thiyagarajan, M.; MacGrogan, D.; Rodgers, J.T.; et al. Neuronal SIRT1 Activation as a Novel Mechanism Underlying the Prevention of Alzheimer Disease Amyloid Neuropathology by Calorie Restriction. J. Biol. Chem. 2006, 281, 21745-21754. [CrossRef] [PubMed]

36. Rühlmann, C.; Wölk, T.; Blümel, T.; Stahn, L.; Vollmar, B.; Kuhla, A. Long-term caloric restriction in ApoE-deficient mice results in neuroprotection via Fgf21-induced AMPK/mTOR pathway. Aging 2016, 8, 2777-2789. [CrossRef]

37. Schafer, M.J.; Alldred, M.J.; Lee, S.H.; Calhoun, M.E.; Petkova, E.; Mathews, P.M.; Ginsberg, S.D. Reduction of beta-amyloid and gamma-secretase by calorie restriction in female Tg2576 mice. Neurobiol. Aging 2015, 36, 1293-1302. [CrossRef] 
38. Karuppagounder, S.S.; Pinto, J.T.; Xu, H.; Chen, H.L.; Beal, M.F.; Gibson, G.E. Dietary supplementation with resveratrol reduces plaque pathology in a transgenic model of Alzheimer's disease. Neurochem. Int. 2009, 54, 111-118. [CrossRef]

39. Lu, C.-H.; Cheng-Yang, H.; Li, C.-Y.; Hsieh, C.-Y.; Ou, H.-T. Lower risk of dementia with pioglitazone, compared with other second-line treatments, in metformin-based dual therapy: A population-based longitudinal study. Diabetologia 2017, 61, 562-573. [CrossRef]

40. Liu, W.; Zhuo, P.; Li, L.; Jin, H.; Lin, B.; Zhang, Y.; Liang, S.; Wu, J.; Huang, J.; Wang, Z.; et al. Activation of brain glucose metabolism ameliorating cognitive impairment in APP/PS1 transgenic mice by electroacupuncture. Free Radic. Biol. Med. 2017, 112, 174-190. [CrossRef]

41. Baur, J.; Pearson, K.J.; Price, N.; Jamieson, H.A.; Lerin, C.; Kalra, A.; Prabhu, V.V.; Allard, J.S.; López-Lluch, G.; Lewis, K.; et al. Resveratrol improves health and survival of mice on a high-calorie diet. Nature 2006, 444, 337-342. [CrossRef]

42. Harrison, D.E.; Strong, R.; Sharp, Z.D.; Nelson, J.F.; Astle, C.M.; Flurkey, K.; Nadon, N.L.; Wilkinson, J.E.; Frenkel, K.; Carter, C.S.; et al. Rapamycin fed late in life extends lifespan in genetically heterogeneous mice. Nature 2009, 460, 392-395. [CrossRef] [PubMed]

43. Mattison, J.A.; Colman, R.J.; Beasley, T.M.; Allison, D.B.; Kemnitz, J.W.; Roth, G.S.; Ingram, D.K.; Weindruch, R.; De Cabo, R.; Anderson, R.M. Caloric restriction improves health and survival of rhesus monkeys. Nat. Commun. 2017, 8, 14063. [CrossRef] [PubMed]

44. Napoli, E.; Schneider, A.; Hagerman, R.; Song, G.; Wong, S.; Tassone, F.; Giulivi, C. Impact of FMR1 Premutation on Neurobehavior and Bioenergetics in Young Monozygotic Twins. Front. Genet. 2018, 9. [CrossRef] [PubMed]

45. Napoli, E.; Schneider, A.; Wang, J.Y.; Trivedi, A.; Carrillo, N.R.; Tassone, F.; Rogawski, M.; Hagerman, R.J.; Giulivi, C. Allopregnanolone Treatment Improves Plasma Metabolomic Profile Associated with GABA Metabolism in Fragile X-Associated Tremor/Ataxia Syndrome: A Pilot Study. Mol. Neurobiol. 2018, 56, 3702-3713. [CrossRef]

46. Song, G.; Napoli, E.; Wong, S.; Hagerman, R.; Liu, S.; Tassone, F.; Giulivi, C. Altered Redox Mitochondrial Biology in the Neurodegenerative Disorder Fragile X-Tremor/Ataxia Syndrome: Use of Antioxidants in Precision Medicine. Mol. Med. 2016, 22, 548-559. [CrossRef]

47. Kaplan, E.S.; Cao, Z.; Hulsizer, S.; Tassone, F.; Berman, R.F.; Hagerman, P.J.; Pessah, I.N. Early mitochondrial abnormalities in hippocampal neurons cultured fromFmr1pre-mutation mouse model. J. Neurochem. 2012, 123, 613-621. [CrossRef] [PubMed]

48. Loesch, D.Z.; Annesley, S.J.; Trost, N.; Bui, M.; Lay, S.T.; Storey, E.; De Piazza, S.W.; Sanislav, O.; Francione, L.M.; Hammersley, E.M.; et al. Novel Blood Biomarkers Are Associated with White Matter Lesions in Fragile X- Associated Tremor/Ataxia Syndrome. Neurodegener. Dis. 2016, 17, 22-30. [CrossRef]

49. Robinson, B.H. [39] Use of fibroblast and lymphoblast cultures for detection of respiratory chain defects. Methods Enzymol. 1996, 264, 454-464. [CrossRef]

50. Bernier, F.; Boneh, A.; Dennett, X.; Chow, C.; Cleary, M.; Thorburn, D. Diagnostic criteria for respiratory chain disorders in adults and children. Neurology 2002, 59, 1406-1411. [CrossRef]

51. Jeon, J.P.; Shim, S.M.; Nam, H.Y.; Baik, S.Y.; Kim, J.W.; Han, B.G. Copy number increase of 1p36.33 and mitochondrial genome amplification in Epstein-Barr virus-transformed lymphoblastoid cell lines. Cancer Genet. Cytogenet. 2007, 173, 122-130. [CrossRef]

52. Petronis, A.; Vincent, J.B.; Surh, L.C.; Ashizawa, T.; Kennedy, J.L. Polyglutamine-containing proteins in schizophrenia: An effect of lymphoblastoid cells? Mol. Psychiatry 2000, 5, 234-236. [CrossRef] [PubMed]

53. Christiansen, G.; Zeuthen, J. Complex forms of mitochondrial DNA in human B cells transformed by Epstein-Barr virus (EBV). J. Cancer Res. Clin. Oncol. 1983, 105, 13-19. [CrossRef] [PubMed]

54. Cahir-McFarland, E.D.; Davidson, D.M.; Schauer, S.L.; Duong, J.; Kieff, E. NF-kappa B inhibition causes spontaneous apoptosis in Epstein-Barr virus-transformed lymphoblastoid cells. Proc. Natl. Acad. Sci. USA 2000, 97, 6055-6060. [CrossRef] [PubMed]

55. Lázló, L.; Tuckwell, J.; Self, T.; Lowe, J.; Landon, M.; Smith, S.; Hawthorne, J.N.; Mayer, R.J. The latent membrane protein-1 in Epstein-Barr virus-transformed lymphoblastoid cells is found with ubiquitin-protein conjugates and heat-shock protein 70 in lysosomes oriented around the microtubule organizing centre. J. Pathol. 1991, 164, 203-214. [CrossRef] [PubMed]

56. Park, G.B.; Kim, Y.S.; Lee, H.-K.; Cho, D.-H.; Kim, D.; Hur, D.Y. CD80 (B7.1) and CD86 (B7.2) induce EBV-transformed B cell apoptosis through the Fas/FasL pathway. Int. J. Oncol. 2013, 43, 1531-1540. [CrossRef] [PubMed]

57. Srimatkandada, P.; Loomis, R.; Carbone, R.; Srimatkandada, S.; Lacy, J. Combined proteasome and Bcl-2 inhibition stimulates apoptosis and inhibits growth in EBV-transformed lymphocytes: A potential therapeutic approach to EBV-associated lymphoproliferative diseases. Eur. J. Haematol. 2008, 80, 407-418. [CrossRef]

58. Bourgeron, T.; Chrétien, D.; Rotig, A.; Munnich, A.; Rustin, P. Isolation and characterization of mitochondria from human B lymphoblastoid cell lines. Biochem. Biophys. Res. Commun. 1992, 186, 16-23. [CrossRef]

59. Chakrabarty, S.; D'Souza, R.R.; Kabekkodu, S.P.; Gopinath, P.M.; Rossignol, R.; Satyamoorthy, K. Upregulation of TFAM and mitochondria copy number in human lymphoblastoid cells. Mitochondrion 2014, 15, 52-58. [CrossRef]

60. Cohen, S.; Masyn, K.; Adams, J.; Hessl, D.; Rivera, S.; Tassone, F.; Brunberg, J.; DeCarli, C.; Zhang, L.; Cogswell, J.; et al. Molecular and imaging correlates of the fragile X-associated tremor/ataxia syndrome. Neurology 2006, 67, 1426-1431. [CrossRef]

61. Bacalman, S.; Farzin, F.; Bourgeois, J.A.; Cogswell, J.; Goodlin-Jones, B.L.; Gane, L.W.; Grigsby, J.; Leehey, M.A.; Tassone, F.; Hagerman, R.J. Psychiatric phenotype of the fragile X-associated tremor/ataxia syndrome (FXTAS) in males: Newly described fronto-subcortical dementia. J. Clin. Psychiatry 2006, 67, 87-94. [CrossRef] 
62. Brunberg, J.A.; Jacquemont, S.; Hagerman, R.J.; Berry-Kravis, E.M.; Grigsby, J.; Leehey, M.A.; Tassone, F.; Brown, W.T.; Greco, C.M.; Hagerman, P.J. Fragile X Premutation Carriers: Characteristic MR Imaging Findings of Adult Male Patients with Progressive Cerebellar and Cognitive Dysfunction. Am. J. Neuroradiol. 2002, 23, 1757-1766.

63. Hall, D.A.; Birch, R.C.; Anheim, M.; Jønch, A.E.; Pintado, E.; O’Keefe, J.; Trollor, J.N.; Stebbins, G.T.; Hagerman, R.J.; Fahn, S.; et al. Emerging topics in FXTAS. J. Neurodev. Disord. 2014, 6, 31. [CrossRef]

64. Ross-Inta, C.; Omanska-Klusek, A.; Wong, S.; Barrow, C.; Garcia-Arocena, D.; Iwahashi, C.; Berry-Kravis, E.; Hagerman, R.J.; Hagerman, P.J.; Giulivi, C. Evidence of mitochondrial dysfunction in fragile X-associated tremor/ataxia syndrome. Biochem. J. 2010, 429, 545-552. [CrossRef]

65. Wang, J.Y.; Hessl, D.; Hagerman, R.J.; Simon, T.J.; Tassone, F.; Ferrer, E.; Rivera, S.M. Abnormal trajectories in cerebellum and brainstem volumes in carriers of the fragile X premutation. Neurobiol. Aging 2017, 55, 11-19. [CrossRef] [PubMed]

66. Sabayan, B.; van der Grond, J.; Westendorp, R.G.; van Buchem, M.A.; de Craen, A.J. Accelerated progression of white matter hyperintensities and subsequent risk of mortality: A 12-year follow-up study. Neurobiol. Aging 2015, 36, 2130-2135. [CrossRef] [PubMed]

67. Boyle, P.A.; Yu, L.; Fleischman, D.A.; Leurgans, S.; Yang, J.; Wilson, R.S.; Schneider, J.A.; Arvanitakis, Z.; Arfanakis, K.; Bennett, D.A. White matter hyperintensities, incident mild cognitive impairment, and cognitive decline in old age. Ann. Clin. Transl. Neurol. 2016, 3, 791-800. [CrossRef] [PubMed]

68. Moura, A.R.; Lee, S.; Habeck, C.; Razlighi, Q.; Stern, Y. The relationship between white matter hyperintensities and cognitive reference abilities across the life span. Neurobiol. Aging 2019, 83, 31-41. [CrossRef] [PubMed]

69. Tsapanou, A.; Habeck, C.; Gazes, Y.; Razlighi, Q.; Sakhardande, J.; Stern, Y.; Salthouse, T.A. Brain biomarkers and cognition across adulthood. Hum. Brain Mapp. 2019, 40, 3832-3842. [CrossRef]

70. Yatawara, C.; Lee, D.; Ng, K.P.; Chander, R.; Ng, D.; Ji, F.; Shim, H.Y.; Hilal, S.; Venketasubramanian, N.; Chen, C.; et al. Mechanisms Linking White Matter Lesions, Tract Integrity, and Depression in Alzheimer Disease. Am. J. Geriatr. Psychiatry 2019, 27, 948-959. [CrossRef] [PubMed]

71. Adams, J.S.; Adams, P.E.; Nguyen, D.; Brunberg, J.A.; Tassone, F.; Zhang, W.; Koldewyn, K.; Rivera, S.M.; Grigsby, J.; Zhang, L.; et al. Volumetric brain changes in females with fragile X-associated tremor/ataxia syndrome (FXTAS). Neurology 2007, 69, 851-859. [CrossRef] [PubMed]

72. Nargund, A.M.; Fiorese, C.J.; Pellegrino, M.W.; Deng, P.; Haynes, C.M. Mitochondrial and nuclear accumulation of the transcription factor ATFS-1 promotes OXPHOS recovery during the UPR(mt). Mol. Cell 2015, 58, 123-133. [CrossRef]

73. Yoneda, T.; Benedetti, C.; Urano, F.; Clark, S.G.; Harding, H.; Ron, D. Compartment-specific perturbation of protein handling activates genes encoding mitochondrial chaperones. J. Cell Sci. 2004, 117, 4055-4066. [CrossRef] [PubMed]

74. Robinson, B.H. Lacticacidemia. Biochemical, clinical, and genetic considerations. Adv. Hum. Genet. 1989, 18, 151-179.

75. Robinson, B.H. Lacticacidemia. Biochim. Biophys. Acta 1993, 1182, 231-244. [CrossRef]

76. Čapková, M.; Houštěk, J.; Hansíková, H.; Hainer, V.; Kunešová, M.; Zeman, J. Activities of cytochrome c oxidase and citrate synthase in lymphocytes of obese and normal-weight subjects. Int. J. Obes. 2002, 26, 1110-1117. [CrossRef] [PubMed]

77. Gropman, A.L. Neuroimaging in Mitochondrial Disorders. Neurotherapeutics 2012, 10, 273-285. [CrossRef]

78. Finsterer, J.; Zarrouk-Mahjoub, S. Cerebral imaging in paediatric mitochondrial disorders. Neuroradiol. J. 2018, 31, 596-608. [CrossRef]

79. Liu, B.; Li, Y.; Stackpole, E.E.; Novak, A.; Gao, Y.; Zhao, Y.; Zhao, X.; Richter, J.D. Regulatory discrimination of mRNAs by FMRP controls mouse adult neural stem cell differentiation. Proc. Natl. Acad. Sci. USA 2018, 115, E11397-E11405. [CrossRef] [PubMed]

80. Weisz, E.D.; Towheed, A.; Monyak, R.E.; Toth, M.S.; Wallace, D.C.; Jongens, T.A. Loss of Drosophila FMRP leads to alterations in energy metabolism and mitochondrial function. Hum. Mol. Genet. 2017, 27, 95-106. [CrossRef]

81. Napoli, E.; McLennan, Y.A.; Schneider, A.; Tassone, F.; Hagerman, R.J.; Giulivi, C. Characterization of the Metabolic, Clinical and Neuropsychological Phenotype of Female Carriers of the Premutation in the X-Linked FMR1 Gene. Front. Mol. Biosci. 2020, 7 , 578640. [CrossRef] [PubMed]

82. Napoli, E.; Flores, A.; Mansuri, Y.; Hagerman, R.J.; Giulivi, C. Sulforaphane improves mitochondrial metabolism in fibroblasts from patients with fragile X-associated tremor and ataxia syndrome. Neurobiol. Dis. 2021, 157, 105427. [CrossRef] [PubMed]

83. Napoli, E.; Tassone, F.; Wong, S.; Angkustsiri, K.; Simon, T.J.; Song, G.; Giulivi, C. Mitochondrial Citrate Transporter-dependent Metabolic Signature in the 22q11.2 Deletion Syndrome. J. Biol. Chem. 2015, 290, 23240-23253. [CrossRef]

84. Napoli, E.; Wong, S.; Giulivi, C. Evidence of reactive oxygen species-mediated damage to mitochondrial DNA in children with typical autism. Mol. Autism 2013, 4, 1-8. [CrossRef]

85. Napoli, E.; Hung, C.; Wong, S.; Giulivi, C. Toxicity of the Flame-Retardant BDE-49 on Brain Mitochondria and Neuronal Progenitor Striatal Cells Enhanced by a PTEN-Deficient Background. Toxicol. Sci. 2013, 132, 196-210. [CrossRef]

86. Giulivi, C.; Napoli, E.; Schwartzer, J.; Careaga, M.; Ashwood, P. Gestational Exposure to a Viral Mimetic Poly(I:C) Results in Long-Lasting Changes in Mitochondrial Function by Leucocytes in the Adult Offspring. Mediat. Inflamm. 2013, $2013,1-8$. [CrossRef] [PubMed]

87. Napoli, E.; Ross-Inta, C.; Wong, S.; Hung, C.; Fujisawa, Y.; Sakaguchi, D.; Angelastro, J.; Omanska-Klusek, A.; Schoenfeld, R.; Giulivi, C. Mitochondrial Dysfunction in Pten Haplo-Insufficient Mice with Social Deficits and Repetitive Behavior: Interplay between Pten and p. PLoS ONE 2012, 7, e42504. [CrossRef] 
88. Giulivi, C.; Zhang, Y.-F.; Omanska-Klusek, A.; Ross-Inta, C.; Wong, S.; Hertz-Picciotto, I.; Tassone, F.; Pessah, I.N. Mitochondrial Dysfunction in Autism. JAMA 2010, 304, 2389-2396. [CrossRef]

89. Nolin, S.; Napoli, E.; Flores, A.; Hagerman, R.; Giulivi, C. Deficits in Prenatal Serine Biosynthesis Underlie the Mitochondrial Dysfunction Associated with the Autism-Linked FMR1 Gene. Int. J. Mol. Sci. 2021, 22, 5886. [CrossRef]

90. Tustison, N.J.; Avants, B.B.; Cook, P.A.; Zheng, Y.; Egan, A.; Yushkevich, P.A.; Gee, J.C. N4ITK: Improved N3 Bias Correction IEEE Trans. Med. Imaging 2010, 29, 1310-1320. [CrossRef]

91. Smith, S.; Zhanga, Y.; Jenkinson, M.; Chenab, J.; Matthews, P.M.; Federico, A.; de Stefano, N. Accurate, Robust, and Automated Longitudinal and Cross-Sectional Brain Change Analysis. NeuroImage 2002, 17, 479-489. [CrossRef] [PubMed]

92. Schmidt, P.; Gaser, C.; Arsic, M.; Buck, D.; Förschler, A.; Berthele, A.; Hoshi, M.; Ilg, R.; Schmid, V.J.; Zimmer, C.; et al. An automated tool for detection of FLAIR-hyperintense white-matter lesions in Multiple Sclerosis. NeuroImage 2012, 59, 3774-3783. [CrossRef]

93. Yushkevich, P.A.; Piven, J.; Hazlett, H.C.; Smith, R.G.; Ho, S.; Gee, J.C.; Gerig, G. User-guided 3D active contour segmentation of anatomical structures: Significantly improved efficiency and reliability. NeuroImage 2006, 31, 1116-1128. [CrossRef] [PubMed]

94. Benjamini, Y.; Hochberg, Y. Controlling the False Discovery Rate: A Practical and Powerful Approach to Multiple Testing. J. R. Stat. Soc. Ser. B 1995, 57, 289-300. [CrossRef] 